\title{
Validation of Organic Farming Technologies in Greater Yam (Dioscorea alata)
}

\author{
P. R. Kamalkumaran ${ }^{1 *}$, M. Velmurugan', M. Anand ${ }^{1}$ and T. Arumugam ${ }^{3}$ \\ ${ }^{1}$ Horticultural Research Station, TNAU, Yercaud, India \\ ${ }^{2}$ Department of Floriculture and Landscape Architecture, TNAU, Coimbatore, India \\ ${ }^{3} \mathrm{HC} \& \mathrm{RI}$, TNAU, Periyakulam, India \\ *Corresponding author
}

Keywords

Alternative farming;

Dioscorea spp.;

Productivity; Tuber

quality; Soil quality

Article Info

Accepted:

12 October 2020

Available Online:

10 November 2020

\begin{abstract}
A B S T R A C T
Global consciousness of food safety, health and environmental issues has stimulated interest in alternative agricultural systems like organic farming. Since information on organic farming of tuber crops is meagre, a field experiment was conducted in over a three-year period at Department of Vegetable Crops, Horticultural College and Research Institute, Tamil Nadu Agricultural University, Coimbatore. The aims were to evaluate the impact of organic, conventional and traditional production systems on yield, proximate composition and mineral content of tubers and soil physico-chemical and biological properties in greater yam (Dioscorea alata). Organic farming (35.14 $\mathrm{t} \mathrm{ha}^{-1}$ ) produced significantly higher yield over conventional practice $\left(28.17 \mathrm{t} \mathrm{ha}^{-1}\right)$ by $24 \%$. A net profit of Rs 3,16,534 ha ${ }^{-1}$, which was $38 \%$ higher over chemical based farming was obtained under organic management in greater yam Tuber quality was improved with slightly higher dry matter, starch and crude protein contents. Thus organic farming was found to be an ecofriendly management strategy in yams for sustainable yield of quality tubers besides maintaining soil health. Technology involving farmyard manure, green manuring, neem cake, biofertilizers and ash was standardized.
\end{abstract}

\section{Introduction}

Worldwide concerns regarding food safety, environmental degradation and threats to human health have generated interest in alternative sustainable agricultural systems (Carter et al., 1993). According to the UN millennium ecosystem assessment, "land degradation" is one of the world's greatest environmental challenges. About $40 \%$ of the world's arable land is seriously degraded and
$11 \%$ of such land is in Asia. The land quality for food production contributes to future peace. Hence "Organic" is essential for sustainable production, protection of soil health and human health besides conservation of environment. It envisages complete exclusion of synthetic chemicals and minimum use of off-farm generated resources or purchased inputs. The current global scenario firmly emphasizes the need to adopt eco-friendly agricultural practices for 
sustainable food production. Organic farming protects the environment, provides better food and living conditions to the human beings. Organic farming is not mere the non use of chemicals in agriculture, but it is a system of farming based on integral interrelationship with components of ecosystem (Lampkin, 1990). Organic manures such as farmyard manure, poultry manure, vermicompost, oil cakes, biofertilizers and bio-wastes are some of the important sources to increase the organic matter content, soil microbial population and to sustain agricultural production by reducing and eliminating the adverse effects of synthetic fertilizers, pesticides etc. The tropical root and tuber crops (cassava, sweet potato, yams, aroids and other minor tuber crops) are food and nutritional crops with adaptation to marginal environments. They form important staple food and are major source of energy especially in the developing countries with rapid population expansion. Tuber crops are also medicinally important and preferred as health foods due to the presence of nutraceuticals and antioxidants. In view of the increased awareness about organic farming, safe food production, increased availability of organic inputs, investigation on these aspects become imperative to assess their effect on yield, quality and post-harvest storage of these crops. Earlier studies conducted at Central Tuber Crops Research Institute indicated that organic management improves yield, quality and soil properties in tuber crops (Suja et al., 2009; 2010; 2012a; 2012b). Hence, the present experiment was conducted to study the effect of organic farming on yield, quality, nutrient uptake and soil fertility in greater yam under Tamil Nadu condition.

\section{Materials and Methods}

The experiment was laid out in randomized block design, with seven replications during 2016-2017 and 2017- 2018 at the Organic Farm, Orchard, Horticultural College and Research Institute, Coimbatore, India. The experimental site is characterized with clay loamy soil texture rich in organic matter content. Coimbatore receives on an average 650- $700 \mathrm{~mm}$ rainfall annually and is situated at an elevation of $426 \mathrm{M}$ (longitude: $77^{\circ} \mathrm{E}$ and latitude: $\left.11^{\circ} \mathrm{N}\right)$. The average annual temperature ranges from $25^{\circ} \mathrm{C}-38^{\circ} \mathrm{C}$. There were a total of three treatments and seven replications. Care was taken to avoid the use of any chemical inputs in organic plots. One was conventional system which was taken outside the organic farm (off- farm). The detailed description of production systems studied is given below.

\begin{tabular}{|c|c|}
\hline Production systems & Description of production systems \\
\hline $\mathbf{T}_{1}$-Conventional & FYM@10 t ha-1 + NPK@ 80:60:80 kg ha ${ }^{-1}$ \\
\hline $\mathbf{T}_{2}$-Traditional & Existing farmers practice \\
\hline$T_{3}$-Organic farming & $\begin{array}{l}\text { FYM@15 } \mathrm{t} \mathrm{ha}^{-1}+\text { green manuring to generate } 15-20 \mathrm{t} \mathrm{ha}^{-1} \text { of green } \\
\text { matter in } 45-60 \text { days }+ \text { neem cake @ } 1 \mathrm{tha}^{-1}+\text { ash @ } 1.5 \mathrm{tha}^{-1}+ \\
\text { biofertilizers }\left(\text { Azospirillum @ } 3 \mathrm{~kg} \mathrm{ha}^{-1} \text {, mycorrhiza @ } 5 \mathrm{~kg} \mathrm{ha}^{-1} \text { and }\right. \\
\text { phosphobacteria@3 } \mathrm{kg} \mathrm{ha}^{-1} \text { ) }\end{array}$ \\
\hline
\end{tabular}

The impact of three production systems viz., Conventional, traditional and organic farming on growth, yield and quality of greater yam as well as economics was evaluate in RBD with seven replications. Chemical inputs were not used for a year prior to the start of the investigations. In "conventional plots", FYM + nitrogen, phosphorus, potassium (NPK) fertilizers were applied. Farmers' practice of using FYM and ash was followed in "traditional plots". In "organic farming plots", FYM, green manure, ash, neem cake and 
biofertilizers (Azospirillum, mycorrhiza and Phosphobacterium) were applied to substitute chemical fertilizers. Organically produced planting materials were used for the study.

The initial and final fertility status of the soil viz., $\mathrm{pH}$, organic $\mathrm{C}$, available $\mathrm{N}$, available $\mathrm{P}$ and available $\mathrm{K}$ are given in Table 1 .

Before planting, the setts were treated with slurry containing $10 \%$ cow dung, $2 \%$ cow urine and $0.5 \%$ each of Trichoderma and Pseudomonas. Treated $100 \mathrm{~g}$ setts were sown at a distance of $90 \mathrm{~cm} \times 90 \mathrm{~cm}$ on the ridges. The gross plot size was $4.5 \mathrm{~m} \times 4.5 \mathrm{~m}$ accommodating twenty five plants. After planting 50\% organic manures were applied as basal and the remaining quantity was applied one month after planting. Off-farm crop was fertilized with recommended dose of nutrients through farmyard manure, urea, super phosphate and muriate of potash.

The observations on yield and quality were recorded at the time of harvest. Tuber from the net plot was harvested, fresh weights were recorded and tuber yield was expressed in tone per hectare. The proximate analyses of tubers for drymatter, starch and crude protein were done using standard procedures. Dry matter and crude protein were determined by the method of AOAC (1980). The starch content was determined by conversion to sugars by acid hydrolysis and then by the method of Dubois et al., (1956).

Soil and plant samples were collected at harvest and analyzed by using standard methods for different parameters. After harvest of the crop, soil samples were collected at $0-15 \mathrm{~cm}$ depth from each plot and analyzed for soil fertility ( $\mathrm{pH}$, organic $\mathrm{C}$ and major nutrients) during both the years. The $\mathrm{pH}$, organic $\mathrm{C}$, available $\mathrm{N}, \mathrm{P}, \mathrm{K}$ status of the soil were estimated by standard analytical methods (Page et al., 1982).

\section{Cost benefit analysis}

Total cost of cultivation and gross returns were calculated from average input cost and average market price of the produce during the period of investigation. Based on this net income was computed as follows:

Net income Indian (Rupees $\mathrm{ha}^{-1}$ ) $=$ Gross income - cost of cultivation

\section{Data collection}

Data were subjected to analysis of variance (ANOVA) using the AGRES statistical programme.

\section{Results and Discussion}

Organic farming is a feasible strategy in greater yam for getting higher yield of quality tubers and safe food. Practical applications and operational methodologies in organic farming, especially in tuber crops, are not available due to lack of comprehensive research in this field. Absence of package of practices recommendations for organic farming of tuber crops hinders the implementation and promotion of this sustainable alternative production system. Many methods and techniques of organic agriculture have originated from various traditional farming systems all over the world, where there is the non-use of chemical inputs.

Organic C, available $\mathrm{N}, \mathrm{P}$ and $\mathrm{K}$ status were also higher in organic plots. Increase in soil organic matter, soil $\mathrm{pH}$, available $\mathrm{P}$ and $\mathrm{K}$ have been measured in some organic systems (Scow et al., 1994; Clark et al., 1998). Similar results have been reported in other crops under Indian conditions as well (Srivastava et al., 2006; Mahapatra et al., 2006). Organic manures help to enhance soil $\mathrm{pH}$ in acidic soils (Mei et al., 2002; Prabhakaran and Pitchai 2002; Prakash et al., 2002). Synthetic 
fertilizer application may have acidified the soil slightly in conventional systems (Barak et $a l ., 1997)$. Higher organic $C$ status of organic plots might be attributed to considerable addition of organic manures particularly green manure cowpea. Higher available $\mathrm{N}$ status may be due to higher $\mathrm{N}$ content in the organic manures, especially green manure used in the study [FYM @ $15 \mathrm{t} \mathrm{ha}^{-1}+$ green manuring to generate 15-20 t ha ${ }^{-1}$ of green matter in 45-60 days + neem cake@1 t ha ${ }^{-1}+$ ash@1.5 tha + biofertilizers (Azospirillum @ 3 kg ha ${ }^{-1}$, mycorrhiza@5 kg ha ${ }^{-1}$ and phosphobacteria (a $3 \mathrm{~kg} \mathrm{ha}^{-1}$ )]. Solubilization of native $\mathrm{P}$ by organic acids during decomposition of organic manures and increased mineralization of $\mathrm{P}$ from the added organic manures might have led to a higher available $\mathrm{P}$ in organic plots. Higher content of $\mathrm{K}$ in the organic manures, especially green manure and ash (FYM, 0.28\%; green manure cowpea, 2.02\%; neem cake, $1.2 \%$; ash, $7.11 \%), \mathrm{K}$ mining effect from the sub surface layers by the extensive root system of green manure crop, organic acid dissolution of inaccessible $\mathrm{K}$ minerals in the soil during green manure decomposition all might have contributed to higher content of available $\mathrm{K}$ in organic plots.

Table.1 Initial and final fertility status of soil

\begin{tabular}{|c|c|c|c|c|c|c|c|c|c|}
\hline \multicolumn{4}{|c|}{ Initial } & \multicolumn{6}{c|}{ Final } \\
\hline $\begin{array}{c}\mathbf{N} \\
\mathbf{( k g} / \mathbf{h a})\end{array}$ & $\begin{array}{c}\mathbf{P} \\
(\mathbf{k g} / \mathbf{h a})\end{array}$ & $\begin{array}{c}\mathbf{K} \\
\mathbf{( k g / h a )}\end{array}$ & $\begin{array}{c}\mathbf{O C} \\
\mathbf{( \% )}\end{array}$ & $\mathbf{p H}$ & $\begin{array}{c}\mathbf{N} \\
(\mathbf{k g} / \mathbf{h a})\end{array}$ & $\begin{array}{c}\mathbf{P} \\
(\mathbf{k g} / \mathbf{h a})\end{array}$ & $\begin{array}{c}\mathbf{K} \\
(\mathbf{k g} / \mathbf{h a})\end{array}$ & $\begin{array}{c}\mathbf{O C} \\
(\mathbf{\%})\end{array}$ & $\mathbf{p H}$ \\
\hline $\mathbf{3 6 5}$ & 33 & 907 & 0.75 & 8.38 & 204 & 23 & 773 & 0.73 & 8.44 \\
\hline
\end{tabular}

Table.2 Yield, quality attributes and economics during 2016-17

\begin{tabular}{|l|c|c|c|c|}
\hline \multicolumn{1}{|c|}{ Treatments } & Yield $\left(\mathbf{t h a}^{\mathbf{- 1}}\right)$ & Dry Matter $\mathbf{( \% )}$ & Starch $(\mathbf{\%})$ & Crude Protein $(\boldsymbol{\%})$ \\
\hline $\mathbf{T}_{\mathbf{1}}$ Conventional & 31.39 & 32.67 & 23.73 & 2.67 \\
\hline $\mathbf{T}_{\mathbf{2}}$ Traditional & 29.49 & 33.35 & 22.96 & 2.23 \\
\hline $\mathbf{T}_{\mathbf{3}}$ Organic & 36.79 & 34.93 & 23.32 & 2.77 \\
\hline SED & 1.85 & 1.08 & 1.02 & 0.21 \\
\hline CD & 3.92 & 2.16 & 2.03 & 0.43 \\
\hline
\end{tabular}

\begin{tabular}{|l|c|c|c|c|}
\hline \multicolumn{1}{|c|}{ Treatments } & Cost of cultivation & Gross Income & Net Income & B:C ratio \\
\hline $\mathbf{T}_{\mathbf{1}}$ Conventional & $1,77,500$ & $4,34,139$ & $2,56,639$ & 2.45 \\
\hline $\mathbf{T}_{\mathbf{2}}$ Traditional & $1,72,500$ & $4,07,861$ & $2,35,361$ & 2.36 \\
\hline $\mathbf{T}_{\mathbf{3}}$ Organic & $1,82,500$ & $5,08,824$ & $3,26,324$ & 2.79 \\
\hline
\end{tabular}

Table.3 Yield, quality attributes and economics during 2017-18

\begin{tabular}{|c|c|c|c|c|}
\hline Entries & Tuber yield $\left(\right.$ tha $\left.^{-1}\right)$ & $\begin{array}{c}\text { Dry Matter } \\
(\%)\end{array}$ & $\operatorname{Starch}(\%)$ & $\begin{array}{c}\text { Crude Protein } \\
(\%)\end{array}$ \\
\hline $\mathrm{T}_{1-}$ - Conventional & 28.56 & 30.06 & 22.07 & 2.72 \\
\hline $\mathbf{T}_{2^{-}}$Traditional & 26.84 & 30.68 & 21.35 & 2.27 \\
\hline $\mathbf{T}_{3-}$ Organic & 33.48 & 32.14 & 21.69 & 2.83 \\
\hline SED & 1.71 & 1.02 & 0.97 & 0.19 \\
\hline CD & 3.63 & 2.05 & 1.93 & 0.41 \\
\hline
\end{tabular}




\begin{tabular}{|l|l|l|l|l|}
\hline Entries & Cost of cultivation & \multicolumn{1}{|c|}{ Gross income } & Net income & B:C ratio \\
\hline $\mathbf{T}_{\mathbf{1}}$ - Conventional & 166850 & 408090.66 & 241240.66 & 2.51 \\
\hline $\mathbf{T}_{\mathbf{2}}$ - Traditional & 162150 & 383389.34 & 221239.34 & 2.40 \\
\hline $\mathbf{T}_{\mathbf{3}}$ - Organic & 171550 & 478294.56 & 306744.56 & 2.81 \\
\hline
\end{tabular}

The present study proves that organic farming involving the use of organic manures helps to restore and improve soil health, by enhancing organic matter levels, neutralising soil acidity, supplying almost all essential nutrients in available form and thereby maintaining soil fertility.

\section{Yield and quality}

Organic farming resulted in $20 \%$ higher yield in greater yam compared to traditional system. The highest yield of tuber was observed in the organic treatment, $\mathrm{T}_{3}[\mathrm{FYM}$ @ $15 \mathrm{t} \mathrm{ha}^{-1}+$ green manuring to generate $15-20 \mathrm{t}$ $\mathrm{ha}^{-1}$ of green matter in 45-60 days + neem cake @ 1 t $\mathrm{ha}^{-1}+$ ash @ $1.5 \mathrm{t} \mathrm{ha}^{-1}+$ biofertilizers (Azospirillum @ $3 \mathrm{~kg} \mathrm{ha}^{-1}$, mycorrhiza@5 kg ha ${ }^{-1}$ and phosphobacteria @ $\left.3 \mathrm{~kg} \mathrm{ha}^{-1}\right)$ ], followed by the conventional treatments, T (FYM @ $10 \mathrm{t} \mathrm{ha}^{-1}+\mathrm{NPK} @$ 80:60:80 kg ha-1).

Integration of organic manure having high $\mathrm{C}: \mathrm{N}$ ratio with manure having low $\mathrm{C}: \mathrm{N}$ ratio increases the mineralization and organic matter build up with efficient microbial activity, which ultimately enhanced the growth and yield of yam.

Similar results were reported by Narayan et al., (2004). The higher yield in these crops may be due to the overall improvement in soil physico-chemical and biological properties under the influence of organic manures (Clark et al., 1998; Colla et al., 2000; Stockdale et al., 2001).

Yield under organic farming is determined by the intensity of external input use before conversion (Stanhill, 1990). Greater yams are traditionally grown with low external inputs using organic wastes and manures available in the homesteads. The yield increase observed in this study is contrary to the majority of reports that crop yields under organic management are 20-40\% lower than for comparable conventional systems (Stockdale et al., 2001).

The biochemical constituents of tubers viz., dry matter, starch and crude protein revealed that production systems significantly influenced these attributes. The treatments had no significant effect on starch content in tuber. However, its effect was significant on dry matter content and crude protein in tuber and organic treatments showed their superiority over conventional and traditional systems.

Organic treatment, $\mathrm{T}_{3}$ significantly improved the contents of dry matter and crude protein in yam. Dry matter content and crude protein of yam showed significant increase with the application of organic manures as compared to integrated use of organic manure and chemical fertilizers and traditional practices (Table 2 and 3).

It could be due to balanced nutrition with favorable physico-chemical and biological conditions of the soil. Rembialkowska (2007) also reported that organic crops contain more dry matter and minerals, especially, $\mathrm{Fe}, \mathrm{Mg}$ and $\mathrm{P}$ (by $21 \%, 29 \%$ and $14 \%$ respectively) over conventionally produced ones. These findings are in accordance with Parthian and Premasekhar (2002) and Azin Ghabelrahmat and Dhumal (2012). 


\section{Economic analysis}

Among the different treatment $\mathrm{T}_{3}$ [FYM @ 15 $\mathrm{t} \mathrm{ha}^{-1}+$ green manuring to generate $15-20 \mathrm{t}$ $\mathrm{ha}^{-1}$ of green matter in 45-60 days + neem cake@1 t ha ${ }^{-1}+$ ash @ 1.5 t ha ${ }^{-1}+$ biofertilizers (Azospirillum @ $3 \mathrm{~kg} \mathrm{ha}^{-1}$, mycorrhiza@5 kg ha ${ }^{-1}$ and phosphobacteria @ $3 \mathrm{~kg} \mathrm{ha}^{-1}$ ] generated average higher net income of Rs.3,16,534 ha ${ }^{-1}$ and B: C ratio of 2.8 followed by $\mathrm{T}_{1}$ [FYM @ $10 \mathrm{t} \mathrm{ha}^{-1}+\mathrm{NPK}$ @ 80:60:80 kg ha ${ }^{-1}$ ] which fetched net income of Rs.2,48,939 ha ${ }^{-1}$ and B:C ratio of 2.48. Organic farming produced significantly higher tuber yield $\left(33.48 \mathrm{tha}^{-1}\right)$ and additional income of Rs. 65,503 and 85,505 ha-1over conventional and traditional practices respectively in greater yam. The higher net income from organic farming is due to the $20 \%$ extra yield obtained over conventional practice (yield increase of 7.3 tha $^{-1}$ )

In summary, organic farming is an ecofriendly farming strategy in yams for getting higher yield of quality tubers and safe food besides maintaining soil health. The physicochemical and biological properties of the soil were also favoured under organic farming. The study proves that for a highly nutrient exhausting crop like greater yam, higher yield can be obtained by using cheaper and on site generated organic manures based on soil testing.

Organic farming also resulted in a healthy crop stand and produced highest tuber yield than that of chemical based farming besides improving the quality of crop as well as soil properties. The technology for organic production in yams comprised of application of FYM @ $15 \mathrm{t} \mathrm{ha}^{-1}+$ green manuring to generate 15-20 tha ${ }^{-1}$ of green matter in 45-60 days+neem cake@1 tha-1 ash@1.5 t ha + biofertilizers (Azospirillum @ $3 \mathrm{~kg} \mathrm{ha}^{-1}$, mycorrhiza @ $5 \mathrm{~kg} \mathrm{ha}^{-1}$ and phosphobacteria @ $\left.3 \mathrm{~kg} \mathrm{ha}^{-1}\right)$. On farm, generation of cheap organic manures like green manures, composts, crop residues etc. will help to make organic farming profitable. However, organic farming if done on equivalent nutrient basis and if premium price is not obtained, it becomes less profitable than chemical farming.

\section{References}

AOAC (1980) Official methods of analysis. Association of Official Agricultural Chemists, Washington DC., pp.169, 611612,1141

Azin Ghabelrahmat and Dhumal, K.N. 2012. Effect of organic manures on growth, yield and nutrient quality of tomato (Lycopersicon esculentum). Green Fmg., 3: $557-559$.

Barak P, Jobe B, Krueger AR, Peterson A, Laird A (1997) Effects of long term soil acidification due to nitrogen fertilizer inputs in Wisconsin. Plant Soil 197:61-69.

Clark, M.S., Horwath, W. R., Shennan, C. and Scow, K. M. 1998. Changes in soil chemical properties resulting from organic and low-input farming systems. Agron. J., 90: 662-671.

Cochran, W. G. and Cox, G.M. 1967. Experimental Design. 2nd Edn. John Wiley \& Sons Inc., New York.

Colla, G., Mitchell, J.P., Joyce, B.A., Huyck, L.M., Wallender, W.W., Temple, S. R., Hsiao, T.C. and Poudel, D.D. 2000. Soil physical properties and tomato yield and quality in alternative cropping systems. Agron. J., 92: 924-932.

Carter, M.E., Gamez, R., Gliessman, S., 1993. Sustainable Agriculture and the Environment in the Humid Tropics, National Academy Press, Washington, DC. pp. 1-191.

Dubois M, Gilles KA, Hamilton JK, Rebers PA, Smith F (1956). Colorimetric method for determination of sugars and related substances. Analytical Chem 28:350-356

Lampkin, N. 1990. Organic Farming. Ipswich, U.K., Farming Press Book. pp. 801-910.

Mahapatra BS, Singh SP, Rajesh A, Vishwakarma VK, Bhushan C, Kumar A, Singh RK, Kumar A, Chilana K, Pandey CS (2006). 
Performance of lentil, chickpea and wheat under organic mode during initial years of conversion in relation to nutrient management practices. J Ecofriendly Agric 1(2):105-116.

Mei C, Yahua S, Zhengguo O, Qirong S (2002) Amelioration of aluminium toxicity with pig manure in an acid red soil. Plant Nutr Fert Sci 8(2): 176.

Narayan, R.N., Magray, G.H., Ahmad, N. and Samantha, A. 2004. Effect of organic manures on nutrient uptake and quality of Capsicum. Hort. J., 17: 141-144.

Page AL, Miller RH, Keeney DR (1982) Methods of soil analysis, part 2: chemical and microbiological properties. American Society of Agronomy, Soil Science Society of America, Madison,Wisconsin, USA, p 1159, Agronomy series no. 9.

Parthian, T. and Premasekhar, M. 2002. Yield and nutrient uptake of hybrid maize as influenced by levels and times of nitrogen fertilization. J. Agric. Resour. Mgmt., 1: 145-149.

Prabhakaran C, Pitchai GJ (2002) Effect of different organic nitrogen sources on $\mathrm{pH}$, total soluble solids, titrable acidity, reducing and non reducing sugars, crude protein and ascorbic acid content of tomato fruits. J Soils and Crops 12(2):160-166.

Prakash YS, Bhadoria PBS, Rakshit A (2002) Comparative efficacy of organic manures on the changes in soil properties and nutrient availability in an alfisol. J Indian Soc Soil Sci 50 (2):219-221.

Rembialkowska, E. 2007. Quality of plant products from organic agriculture. J. Sci. Food and Agric., 87: 2757-2762.

Sadasivam, S. and Manickam, A. 2008. Biochemical Methods. New Age International Publishers, New Delhi. 270 p.
Scow KM, Somasco O, Gunapala N, Lau S, Venette R, Ferris H, Miller R, Shenman C (1994) Transition from conventional to low-input agriculture changes soil fertility and biology. California Agric 48:20-26.

Srivastava AK, Singh S, Shivankar VJ, Das AK, Rao CN (2006). Organic citrus status. National Research Centre for Citrus, Nagpur, Maharashtra.

Stanhill, G. 1990. The comparative productivity of organic agriculture. Agric. Ecosyst. Environ., 30: 1-26.

Stockdale, E.A., Lampkin. N. H., Hovi, M., Keating, R., Lennartsson, E. K. M., Macdonald, D. W., Pade, 1 S., Tattersall, F. H., Wolfe, M.S. and Watson, C. A. 2001. Agronomic and environmental implications of organic farming systems. Adv. Agron., 70: 261-327.

Suja, G., Sreekumar, J., Susan John, K. and Sundaresan, S. 2012a. Organic production of tuberous vegetables: Agronomic, nutritional and economic benefits. J. Root Crops, 38: 135-141.

Suja, G., Sundaresan, S., Susan John, K., Sreekumar, J. and Misra, R. S. 2012b. Higher yield, profit and soil quality from organic farming of elephant foot yam. Agron. Sustain. Dev., 32: 755-764. (doi 10. 1007/s 13593-011-0058-5).

Suja, G., Susan John, K., Ravindran, C. S., Prathapan, K. and Sundaresan, S. 2010. On farm validation of organic farming technology in elephant foot yam (Amorphophallus paeoniifolius Dennst. Nicolson). J. Root Crops, 36: 59-64.

Suja, G., Susan John, K. and Sundaresan, S. 2009. Potential of tannia (Xanthosoma sagittifolium L.) for organic production. J. Root Crops, 35: 36-40.

\section{How to cite this article:}

Kamalkumaran, P. R., M. Velmurugan, M. Anand and Arumugam, T. 2020. Validation of Organic Farming Technologies in Greater Yam (Dioscorea alata). Int.J.Curr.Microbiol.App.Sci. 9(11): 1436-1442. doi: https://doi.org/10.20546/ijcmas.2020.911.169 